\title{
OPINIONES
}

\section{What can possibly go wrong? The risks of introducing soil microorganisms from Antarctica into South America}

\author{
¿Qué puede salir mal? Los riesgos de introducir microorganismos del suelo \\ de la Antártida en América del Sur
}

\author{
Martin A Nuñez ${ }^{\text {a*}, ~ R o m i n a ~ D ~ D i m a r c o b ~}{ }^{b}$ Ian A Dickie ${ }^{c}$, Aníbal Pauchard ${ }^{\text {dee }}$ \\ *Corresponding author: a Universidad Nacional del Comahue, INIBIOMA, CONICET, Grupo de Ecología de Invasiones, \\ Quintral 1250, C.P. 8400, Bariloche, Argentina, phone: +54 9294 4570021, nunezm@gmail.com \\ ${ }^{\mathrm{b}}$ INTA-CONICET, Grupo de Ecología de Poblaciones de Insectos (GEPI), Bariloche, Argentina. \\ ${ }^{c}$ Lincoln University, Bio-Protection Research Centre, Lincoln, New Zealand. \\ ${ }^{d}$ Universidad de Concepción, Facultad de Ciencias Forestales, Laboratorio de Invasiones Biológicas (LIB), Concepción, Chile. \\ ${ }^{\mathrm{e}}$ Institute of Ecology and Biodiversity (IEB), Chile.
}

\begin{abstract}
SUMMARY
Endophytic fungi form mutualistic associations with plant roots which can increase plant survival and resistance to stress. Recently, it has been proposed that endophytic fungi from Antarctica should be used to facilitate reintroduction and establishment of native plants in xeric environments of northern Chile. In this note, we suggest this is a risky proposition and may lead to biological invasions. It is difficult to predict which endophytic fungi will become invasive, where they will invade, or what their impacts will be. Organisms that move across continents may or may not become invasive depending on the interaction between the species and the invaded community; unexpected outcomes may occur due to adaptation and novel interactions of the introduced species in the new environment. The fact that these endophytes are mutualistic does not imply that they will not have negative effects on the recipient community, since they might promote invasion of other non-native species or may change the competitive relationships among native species. Further, taxonomically uncharacterized fungal isolates from plant roots are likely to contain non-beneficial species. The fact that these endophytic fungi species are from Antarctica does not ensure that they cannot invade elsewhere. It should be recognized that invasive microorganisms are extremely difficult to control. We strongly suggest that the further translocation, use and spread of endophytes from Antarctica should be halted until a risk assessment is undertaken. Biosecurity measures must be taken when considering transcontinental experiments. Based on previous experiences, it is likely that the risk and potential costs of introducing these new species significantly exceed any potential benefits of their introductions.
\end{abstract}

Key words: biological invasions, endophytes, fungi, pathogens, soil biota.

\section{RESUMEN}

Los hongos endófitos forman asociaciones mutualísticas con raíces de plantas y pueden mejorar la sobrevivencia y resistencia al estrés. Recientemente se ha propuesto usar hongos endófitos de la Antártida para facilitar la reintroducción y establecimiento de plantas nativas en formaciones xerofíticas del norte de Chile. En esta nota se sugiere que aquello es una propuesta riesgosa y puede conducir a invasiones biológicas. Es difícil predecir qué especies se convertirán en invasoras, dónde lo harán o cuáles serán sus efectos. Los organismos transportados entre continentes pueden o no convertirse en invasores, según las interacciones entre especies y con la comunidad invadida, y pueden ocurrir resultados inesperados debido a adaptaciones de especies invasoras al nuevo ambiente y a novedosas interacciones con especies introducidas en el nuevo ambiente. Estos endófitos mutualistas pueden tener efectos negativos en la comunidad receptora, como promover invasiones de otras especies exóticas o cambiar relaciones de competencia entre especies nativas. Los hongos endófitos de la Antártida no garantizan que no puedan invadir otros lugares. La falta de identificación taxonómica de tales hongos impide saber si estos inóculos contienen especies no beneficiosas, como patógenos del suelo. Los microorganismos invasores son extremadamente difíciles de controlar. Por ello, se recomienda que la translocación, uso y dispersión de hongos endófitos antárticos debiera detenerse hasta tener una evaluación del riesgo de su introducción. Medidas de bioseguridad deben tomarse en experimentos transcontinentales. Según experiencias anteriores, el riesgo y costos potenciales de introducir estas especies pueden superar ampliamente cualquier beneficio potencial de su uso.

Palabras clave: invasiones biológicas, endófitos, hongos, patógenos, biota del suelo. 


\section{INTRODUCTION}

Biological invasions are a leading cause of global change, affecting conservation of biodiversity, economies and human health (Mack et al. 2000). Despite the well known impacts of invasions (Simberloff et al. 2013) there are continued attempts to introduce new species to novel habitats with little or no consideration of the potential risk for both the environment and human well-being, and the associated economic costs. The introduction of organisms that are poorly understood in terms of their ecological impacts, capacity to invade and social benefits is especially problematic. This is the case of the introduction of most soil organisms (Schwartz et al. 2006, Vellinga et al. 2009), including the translocation of endophytic fungal species from Antarctica to South America proposed by Fardella et al. (2014) in a recent issue of Bosque.

The goal of this article is to discuss potential problems of the introduction of endophytic fungi from Antarctica as recently undertaken by Fardella et al. (2014) to promote the establishment of native plants in areas with high water stress in the north of Chile. Fardella et al. (2014) have found that the addition of root-associated Antarctic endophytic fungi can have positive effects by increasing or maintaining survivorship in three native plant species, facilitating establishment of native plants and restoration efforts in extreme climatic habitats. However, despite these benefits, we need to consider that the potential problems may far exceed the benefits of these new introductions. In the case of Fardella et al. (2014), the introduction has already taken place as part of the research program. Hence this is a critical debate to resolve before further introductions from Antarctica take place.

\section{CAN NONNATIVE MUTUALISTS BE A PROBLEM?}

Endophytic fungi are generally beneficial to plants. For example, they can help improve resistance against herbivory by insects and mammals and tolerance to stress (e.g. drought) (Clay 1988, Cheplick and Faeth 2009). It may not be surprising that much of the international concern over invasive species is around species with "negative" interactions: strong competitors, pathogens and predators (Luque et al. 2013). This raises a critical question of whether and how a "beneficial nonnative species" could have negative effects. There are three clear mechanisms by which introduced mutualists can have strong negative effects; through (1) indirect effects on plant communities, (2) direct effects on resident, native mutualist microorganism and (3) through effects on other trophic levels, particularly herbivores in the case of endophytic fungi.

Perhaps the most globally-widespread intentional introductions of soil mutualists have involved mycorrhizal fungi. These fungi have been primarily introduced for the purpose of promoting plant productivity (Schwartz et al. 2006, Vellinga et al. 2009, Nuñez and Dickie 2014). It is now recognized that these introduced fungi are being spread well beyond their areas of initial introduction (Nuñez et al. 2013, Wood et al. 2015) and are facilitating the spread of invasive trees (Nuñez et al. 2009, Dickie et al. 2010). Sometimes, a single fungal species is enough to trigger the invasion of nonnative trees (Hayward et al. 2015). Plant-fungal co-invasions (when both nonnative species invade together) are associated with major changes in soil nutrient cycling, particularly with the movement of soil nutrients from recalcitrant into more labile pools, facilitating subsequent invasion by other nonnative plants (Dickie et al. 2014).

There is inconsistent evidence on whether invasive mutualists might influence native mutualist communities. Nuñez and Dickie (2014) suggest that low diversity mutualist communities such as $\mathrm{N}$-fixing Rhizobia may have larger potential loss of biodiversity following invasion than higher diversity ectomycorrhizal communities (see, Rodriguez-Echeverria 2010, Wolfe et al. 2010). It is clear that more research is needed in this particular topic but it appears that the introduction of soil mutualists can have large effects on native mutualist communities (Schwartz et al. 2006).

The most important concern over introduced endophytes might be their potential impacts on native herbivores. Fardella et al. (2014) suggest that one of the endophytic fungal species that they introduced might increase plant growth and survival by reducing insect herbivory on roots. By providing protection only to some plants, introduced endophytes will change the competitive hierarchies of plants (Omacini 2014). Further non-target effects may be on grazing mammals. Endophytes that reduce insect herbivory on roots also cause the death of cattle, horse and sheep (Clay 1988). We also note that insect herbivores are a critical component of biodiversity; hence the logic of restoring native vegetation at the expense of native invertebrates poses doubts, as the effects on insect biodiversity are still unknown.

\section{CAN SPECIES FROM ANTARCTICA BECOME INVASIVE?}

It is hard to predict which species will invade and which ones will not (Enserink 1999). It has been historically proposed that species from some areas are more prone to invade than others. Eurasian species have been proposed as having advantages when introduced to new areas, given perhaps their longer coevolutionary history with humans (among other hypotheses) (Di Castri 1989). However, this might be just an artifact of efforts to introduce Eurasian species, rather than something intrinsic or superior about these species (Jeschke and Strayer 2005).

Antarctica is a very sensitive place to invasion (Chown et al. 2012). However, this is no reason to think that species from Antarctica cannot invade elsewhere. Species from areas well known to be highly vulnerable to invasions, as 
is the case of Pacific or South Atlantic islands, have been shown to be invasive elsewhere. Although Hawaii has a strong history of invasion and the government spends millions of dollars to control invasions, a plant native from this island, Scaevola taccada (Gaertn.) Roxb., is among the most problematic invasive species in Florida, USA (Gordon 1998). A snail from New Zealand, Potamopyrgus antipodarum (Gray, 1843), reaches very high densities and is an aggressive invader in different parts of the world (Ponder 1988). An insect from the Malvinas islands has become a pest in other islands (Laparie et al. 2010). These are examples of the risk of invasion even of species originating from areas prone to invasion as is the case for Antarctica.

\section{IF ENDOPHYTES BECOME A PROBLEM, HOW FEASIBLE IS IT TO CONTROL THEM?}

Biosecurity measures to prevent introduction of unknown or unwanted species must always be taken when introducing species from different geographic regions (Hulme 2011). Translocations of fungi and fungi-like organisms have resulted in the death of millions (Irish Potato Famine), the loss of forest dominants (Chestnut blight, Sudden Oak Death) and the collapse of economies (Rubber leaf blight, Coffee rust). Under certain legal definitions, the endophytic fungal species introduced by Fardella et al. (2014) could be considered native to Chile, though species are really native to ecosystems, disregarding political borders. Nonetheless, the fact that these endophytes are from a different continent and biogeographic region should be enough evidence to enforce strict biosecurity measures (e.g., risk assessments) on attempts to introduce them into South America.

The control of nonnative species that are visible to the naked eye is complicated and challenging; nevertheless, controlling microbial species may be even more complicated, if it is even possible. There are standard methods to control invasive plants (e.g. herbicide applications) and animals (e.g. hunting, poison, biocontrol), though there are no standard methods for controlling fungi. Using fungicide can be an option; nonetheless, its effect seems to be too local for efficient control. Fungi spores are likely to spread quickly from sites of introduction and, once present, spores of some soil mutualists can live decades or hundreds of years in the soil (Bruns et al. 2009, Nguyen et al. 2012). Given the current lack of effective methods, any problems that might arise from introducing endophytes would present a severe challenge for future control. This is particularly the case in South America, where resources allocated to control invasive species are restricted (Nuñez and Pauchard 2010).

It is also important to note that Fardella et al. (2014) have introduced fungi without robust characterization of which fungal species were being introduced. Current molecular techniques to identify species (Sun and Guo 2012) are readily available, robust and should be used. One could also question whether the deliberate introduction of uncharacterized fungal strains is wise, given the potential for introducing pathogenic strains. If these species spread, future control efforts may be compromised by difficulties knowing if these fungi are native or not to South America (Pringle and Vellinga 2006).

\section{CONCLUDING REMARKS}

The introduction of soil microorganisms without proper control is an immense risk for local ecosystems and economies. The fact that microorganisms are considered beneficial does not imply that they are risk free. Nor does the Antarctican origin imply that species will not become invasive. A central problem with the introduction of soil microorganism is that they are extremely difficult to control and their impacts are unpredictable. This is even more problematic if the introduced species are not properly identified, which can be avoided by using current molecular techniques to identify species. We strongly advise that the use and spread of endophyte fungi from Antarctica be halted until proper biosecurity protocols are considered. Based on previous experiences from different parts of the world with many different types of organisms, it is likely that the risk of introducing these new species far exceeds the potential benefits of their introduction.

\section{REFERENCES}

Bruns TD, KG Peay, PJ Boynton, LC Grubisha, NA Hynson, NH Nguyen, NP Rosenstock. 2009. Inoculum potential of Rhizopogon spores increases with time over the first $4 \mathrm{yr}$ of a 99-yr spore burial experiment. New Phytologist 181: 463-470.

Clay K. 1988. Fungal endophytes of grasses: a defensive mutualism between plants and fungi. Ecology 69: 10-16.

Cheplick GP, SH Faeth. 2009. Ecology and evolution of the grass-endophyte symbiosis. Oxford, England. Oxford University Press. 256 p.

Chown SL, AHL Huiskes, NJM Gremmen, JE Lee, A Terauds, K Crosbie, Y Frenot, KA Hughes, S Imura, K Kiefer, M Lebouvier, B Raymond, M Tsujimoto, C Ware, B Van de Vijver, DM Bergstrom. 2012. Continent-wide risk assessment for the establishment of nonindigenous species in Antarctica. Proceedings of the National Academy of Sciences 109: 4938-4943.

Di Castri F. 1989. History of biological invasions with special emphasis on the Old World. In Drake JA editor. Biological invasions: a global perspective. Chichester, New York. Wiley. p. 1-30.

Dickie IA, N Bolstridge, JA Cooper, DA Peltzer. 2010. Co-invasion by Pinus and its mycorrhizal fungi. New Phytologist 187: 475-484.

Dickie IA, MG St John, GW Yeates, CW Morse, KI Bonner, K Orwin, DA Peltzer. 2014. Belowground legacies of $P i$ nus contorta invasion and removal result in multiple mechanisms of invasional meltdown. AoB Plants. 6: plu056 
doi: 10.1093/aobpla/plu056

Enserink M. 1999. Predicting invasion: Biological invaders sweep in. Science 285: 1834-1836.

Fardella C, R Oses, C Torres-Díaz, MA Molina-Montenegro. 2014. Hongos endófitos antárticos como herramienta para la reintroducción de especies nativas en zonas áridas. Bosque 35(2): 235-239.

Gordon DR. 1998. Effects of invasive, non-indigenous plant species on ecosystem processes: lessons from Florida. Ecological Applications 8: 975-989.

Hayward JA, TR Horton, A Pauchard, MA Nuñez. 2015. A single ectomycorrhizal fungal species can enable a Pinus invasion. Ecology 96(5): 1438-1444.

Hulme PE. 2011. Biosecurity: the changing face of invasion biology. In Richardson DM ed. Fifty Years of Invasion Ecology. Oxford, England. Wiley-Blackwell. 301 p.

Jeschke JM, DL Strayer. 2005. Invasion success of vertebrates in Europe and North America. PNAS: 0501271102.

Laparie M, M Lebouvier, L Lalouette, D Renault. 2010. Variation of morphometric traits in populations of an invasive carabid predator (Merizodus soledadinus) within a sub-Antarctic island. Biological Invasions 12: 3405-3417.

Luque GM., C Bellard, C Bertelsmeier, E Bonnaud, P Genovesi, D Simberloff, F Courchamp. 2013. Alien species: Monster fern makes IUCN invader list. Nature 498: 37.

Mack RN, D Simberloff, W M. Lonsdale, H Evans, M Clout, FA Bazzaz. 2000. Biotic invasions: Causes, epidemiology, global consequences, and control. Ecological Applications 10: 689-710.

Nguyen NH, NA Hynson, TD Bruns. 2012. Stayin' alive: survival of mycorrhizal fungal propagules from 6-yr-old forest soil. Fungal Ecology 5: 741-746.

Nuñez MA, IA Dickie. 2014. Invasive belowground mutualists of woody plants. Biological Invasions 16: 645-661.

Nuñez MA, J Hayward, TR Horton, GC Amico, RD Dimarco, MN Barrios-Garcia, D Simberloff. 2013. Exotic mammals disperse exotic fungi that promote invasion by exotic trees. PLOS ONE 8: e66832.

Nuñez MA, TR Horton, D Simberloff. 2009. Lack of belowground mutualisms hinders Pinaceae invasions. Ecology
90: 2352-2359.

Nuñez MA, A Pauchard. 2010. Biological invasions in developing and developed countries: does one model fit all? Biological Invasions 12: 707-714.

Omacini M. 2014. Asexual endophytes of grasses: invisible symbionts, visible imprints in the host neighborhood. In Verma VC and AC Gange eds. Advances in Endophytic Research. Springer. 143-157 p.

Ponder W. 1988. Potamopyrgus antipodarum - a molluscan coloniser of Europe and Australia. Journal of Molluscan Studies 54: 271-285.

Pringle A, EC Vellinga. 2006. Last chance to know? Using literature to explore the biogeography and invasion biology of the death cap mushroom Amanita phalloides (Vaill. Ex fr.: Fr.) link. Biological Invasions 8: 1131-1144.

Rodriguez-Echeverria S. 2010. Rhizobial hitchhikers from Down Under: invasional meltdown in a plant-bacteria mutualism? Journal of Biogeography 37: 1611-1622.

Schwartz MW, JD Hoeksema, CA Gehring, NC Johnson, JN Klironomos, LK Abbott, A Pringle. 2006. The promise and the potential consequences of the global transport of mycorrhizal fungal inoculum. Ecology Letters 9: 501-515.

Simberloff D, J-L Martin, P Genovesi, V Maris, DA Wardle, J Aronson, F Courchamp, B Galil, E García-Berthou, M Pascal, P Pyšek, R Sousa, E Tabacchi, M Vilà. 2013. Impacts of biological invasions: what's what and the way forward. Trends in Ecology \& Evolution 28: 58-66.

Sun X, LD Guo. 2012. Endophytic fungal diversity: review of traditional and molecular techniques. Mycology 3(1): 65-76.

Vellinga EC, BE Wolfe, A Pringle. 2009. Global patterns of ectomycorrhizal introductions. New Phytologist 181: 960-973.

Wolfe BE, F Richard, HB Cross, A Pringle. 2010. Distribution and abundance of the introduced ectomycorrhizal fungus Amanita phalloides in North America. New Phytologist 185: 803-816.

Wood JR, IA Dickie, HV Moeller, DA Peltzer, KI Bonner, G Rattray, JM Wilmshurst. 2015. Novel interactions between non-native mammals and fungi facilitate establishment of invasive pines. Journal of Ecology 103(1): 121-129. DOI: $10.1111 / 1365-2745.12345$ 